\title{
NITROGEN EFFECIENCY IN MAIZE UNDER SALINE-SODIC CONDITIONDS AS AFFECTED BY UREA IN COMBINATION WITH SOME ORGANIC AMENDMENTS \\ Abdel-Aziz, M. F. ${ }^{1}$; Rania M. El-Shal' ${ }^{2}$ and Dalia A. Sayed ${ }^{1}$ \\ ${ }^{1}$ Soil, Water and Environmental Res. Institute, ARC, Giza, Egypt. \\ ${ }^{2}$ Soil and Water Dept., Faculty of Agriculture, Tanta Univ.Egypt.
}

\begin{abstract}
Effects of application of organic amendments i.e, compost (COM), farmyard manure (FYM) and town refuse manure (TR) (at a rate of $5 \mathrm{Mg} \mathrm{fed}^{-1}$ corresponding to $12 \mathrm{Mg} \mathrm{ha}^{-1}$ ) with or without different levels of $\mathrm{N}$ (i.e, $0,60,90$ and $120 \mathrm{~kg} \mathrm{~N}$ fed. ${ }^{-1}$, corresponding to $0,143,215$ and $286 \mathrm{~kg} \mathrm{~N}^{-1}$ ) in the form of urea on maize (Zea mays L. cv. Triple hybrid 310) grown on a saline-sodic loamy sand soil at Gelbana village, Northern Sinai Governorate, Egypt were studied during the two successive summer seasons of 2013 and 2014. The treatments were arranged in a randomized complete block design with three replicates. Soil content of available N, P, K, Fe, Mn and $\mathrm{Zn}$ increased whereas the electrical conductivity $\left(\mathrm{EC} \mathrm{dSm}{ }^{-1}\right)$ and soil $\mathrm{pH}$ values decreased due to these treatments. The applied organic amendments and urea as well as their combinations, generally increased significantly all the growth parameters i.e. plant height, grain weight ear $^{-1}$ and 100 -grain weight and consequently grain yield in the two growing seasons. Values of $\mathrm{N}, \mathrm{P}, \mathrm{K}$ Fe, $\mathrm{Mn}$ and $\mathrm{Zn}$ uptake by maize plant increased significantly in both the growing seasons.

The highest values of apparent nitrogen recovery (ANR) were obtained due to the treatment $T R+\left(90 \mathrm{~kg} \mathrm{~N}\right.$ fed. $\left.{ }^{-1}\right)$ at the two growing seasons, however, the highest nitrogen agronomic efficiency (NAE) was obtained owing to the treatment consisting of $\mathrm{COM}+\mathrm{N}$ at a rate of $60 \mathrm{~kg} \mathrm{~N}$ fed. $^{-1}$. Proline content decreased with increasing $\mathrm{N}$ rate up to $120 \mathrm{~g} \mathrm{~N} \mathrm{fed.}^{-1}$; however, the highest proline content (5.94 $\square \mathrm{g} \mathrm{g}^{-1}$ fresh weight) was obtained due to application of TR without urea fertilizer. In the contrary, total chlorophyll content increased with increasing $\mathrm{N}$ rate up to $120 \mathrm{~kg} \mathrm{~N}$ fed. $^{-1}$ which resulted in the highest content of chlorophyll when this rate of $\mathrm{N}$ was accompanied with $\mathrm{COM}$ during the two growing seasons. The highest rate of $\mathrm{N}$ fertilization i.e., 120 $\mathrm{kg} \mathrm{N}$ fed. $^{-1}$ combined with TR or FYM compost was of the most superior effect on protein content and nutrient contents. This was found to be true for both 2013 and 2014 seasons.
\end{abstract}

Keywords: Saline-sodic soil, urea, compost, FYM, town refuse and maize.

\section{INTRODUCTION}

Soil salinity is of major concern in agriculture all over the world because it affects almost all plant functions. More than $6 \%$ of the world's land and more precisely, one third of the world's irrigated land is significantly affected by soil salinity (FAO, 2008). Soil salinization is a major process of land degradation that decreases soil fertility and crop productivity (Haque, 2006).

The influences of organic residues such as town refuse (TR) and farmyard manure (FYM) on crop yield have been found to be variable and dependent on their elemental composition and application rate beside their selves are sources of both macro and micronutrients, (Khalifa et al., 1994). Large amounts of municipal solid wastes are generated from different 
sources reaching $30 \mathrm{Mg} \mathrm{day}^{-1}$; however, their potential value is almost ignored. Aerobic composting of the organic fraction of town refuse was carried out to raise its fertilizing value using different accelerators, (Abd ElMaksoud, 2002). Mohamed and Matloub (2007) suggested that the favorable effect of town refuse on enhancing the physical properties of soils may be attributed to their high content of organic matter. Ahmad et al. (2001) indicated that the N, P and K contents of soil treated with organic manures were significantly higher than the corresponding contents of chemical fertilizer treated one. Khalifa et al. (1994) reported that the application of FYM and TR in sandy soil increased the available contents of $\mathrm{Fe}, \mathrm{Mn}$ and $\mathrm{Zn}$ in soil. Sarwar et al. (2008) indicated that the combined application of both organic and inorganic fertilizers improved chemical properties of soil and enriched the fertility of soil. Arthur et al. (2011) found that the COM application decreased $\mathrm{pH}$ of soils particularly at its high application rates.

The COM can be a very good organic amendment in saline agriculture as well as for reclamation of salt-affected soils (Zaka et al., 2003). Mohamed and Matloub (2007) reported that the highest reduction in the EC value was in the soil surface of soil treated with TR. Cengiz et al. (2013) found that the plant pigments such as chlorophylls a and b decreased markedly in maize plants due to salinity stress which on, the other hand, caused a marked increase in the levels of free proline in maize plants. Raafat and Tharwat (2011) found that the organic amendments improved soil properties and nutritional status even under soil salinity. Rashed (2006) reported that the soil content of available $\mathrm{N}$ - increased as the level of mineral $\mathrm{N}$ fertilization increased.

Maize as one of the important cereal crops in Egypt needs high rate of $\mathrm{N}$-up to $300 \mathrm{~kg}$ urea fed. ${ }^{-1}$ in normal soils (Nofal and Hinar 2003). El- Bana and Gomaa (2000) found a significant increase in grain content of $\mathrm{N}$ as a result of increasing levels of applied nitrogen from 100 to $120 \mathrm{~kg} \mathrm{~N}$ fed. ${ }^{-1}$.

The current experiment aims at investigating the effects of different organic amendments i.e. compost manure (COM), farmyard manure (FYM) and town refuse (TR) combined with or without urea on growth parameters and grain yield of maize grown on a saline -sodic soil at Gelbana village , Sahl-El-Tina , Sinai. Maize plant contents of some nutritional elements as well as its contents of proline and chlorophyll beside of the $\mathrm{N}$ use efficiencies were also detrmined at this investigation.

\section{MATERIALS AND METHODS}

A filed experiment was carried out on maize (Zea mays, Triple hybrid 310) grown on a saline-sodic loam sandy soil at Gelbana village, Sahl- ElTina in North- Western of Sinai, Egypt, during the two successive summer seasons of 2013 and 2014. The purposes of this experiment were to investigate the effects of mineral $\mathrm{N}$ - fertilization at four levels $0,60,90$ and $120 \mathrm{~kg}$ $\mathrm{N}$ fed. ${ }^{-1}$ corresponding to $0,143,215$ and $286 \mathrm{~kg} \mathrm{~N} \mathrm{ha}^{-1}$, respectively) as urea (460 $\mathrm{g} \mathrm{N} \mathrm{kg}^{-1}$ ) along with organic manures i.e. compost (COM), farmyard manure (FYM) and town refuse (TR) at a rate of $5 \mathrm{Mg} \mathrm{fed}^{-1}\left(12 \mathrm{Mg} \mathrm{ha}^{-1}\right)$, on growth 
parameters, grain yield and grain quality as well as macro and micro-nutrient uptake by maize.

A representative soil sample from the investigated soil was taken before planting from $0-30 \mathrm{~cm}$ layer and used for determining some physical and chemical properties according to the standard method given thereafter by Piper (1950) and Page et al. (1982). These properties are given in Table 1.

Table 1. Physical and chemical properties of the investigated soil

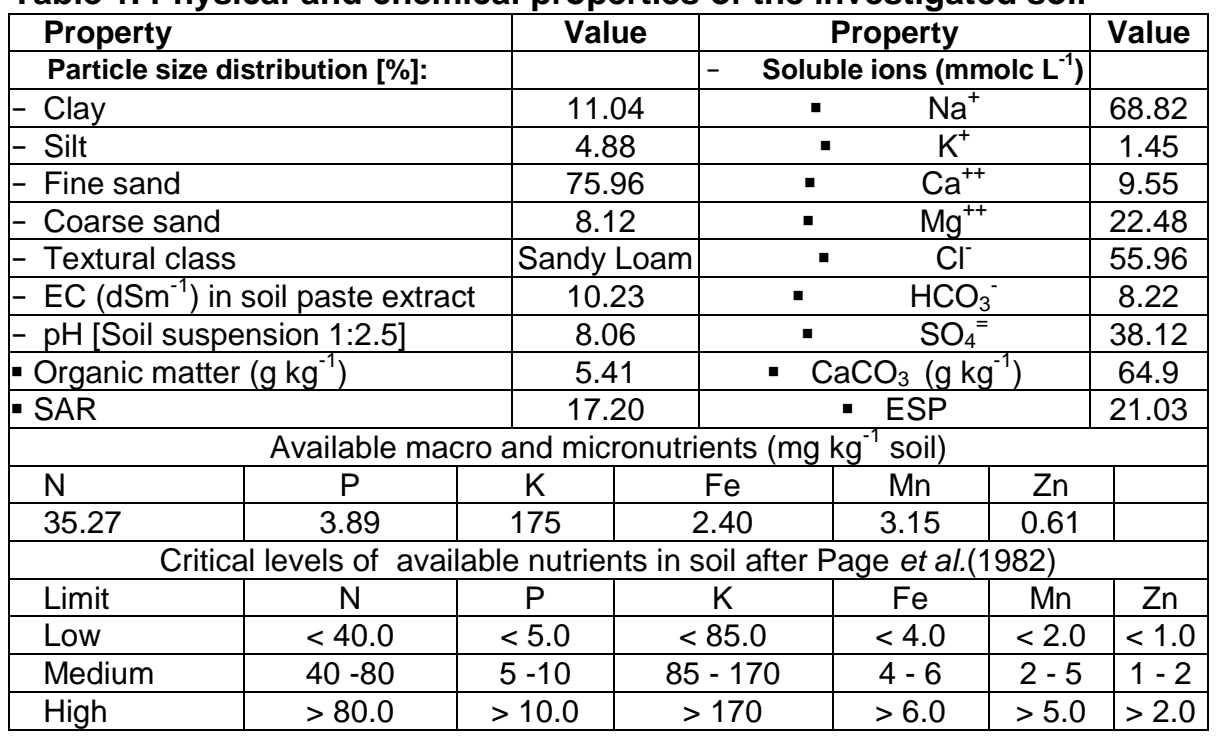

The soil experimental field was pre-treated by applying the gypsum requirements to soil which was then plowed to a depth of $30 \mathrm{~cm}$. Thereafter, continuous leaching process was carried out through adding water to soil basins until it reached a height of $15 \mathrm{~cm}$ above the soil surface then kept constant for 3 days. Two weeks later, lazar technique was used for leveling the soil surface followed by deep sub-soiling plowing and establishing field drains at a depth of $90-\mathrm{cm}$ at the beginning of each drain followed by establishment of an irrigation canal in the middle part of the experimental area. The soil was irrigated from El-Salam Canal (a mixture of Nile water and agricultural drainage water at rate of 1:1), (Table 2).

To control soil salinity, water was applied immediately after sowing for 4 hours and then the excess water was drained. This process was repeated once again in the second day. After that, irrigation water was added every 10 days until the end of the growing seasons. 
Table 2. Chemical properties of the irrigation water in the two successive years of study

\begin{tabular}{|l|r|c|}
\hline \multirow{2}{*}{ Property } & $\mathbf{2}$ Season \\
\cline { 2 - 3 } & $\mathbf{2 0 1 3}$ & $\mathbf{2 0 1 4}$ \\
\hline $\mathrm{pH}$ & 7.89 & 7.93 \\
\hline $\mathrm{EC}\left(\mathrm{dSm}^{-1}\right)$ & 1.46 & 1.32 \\
\hline \multicolumn{3}{|c|}{ Macronutrient $\left(\mathrm{mg} \mathrm{kg}^{-1}\right)$} \\
\hline $\mathrm{NH}_{4}{ }^{+}-\mathrm{N}$ & 7.99 & 6.55 \\
\hline $\mathrm{NO}_{3}{ }^{-}-\mathrm{N}$ & 7.32 & 7.68 \\
\hline $\mathrm{P}$ & 2.08 & 2.14 \\
\hline $\mathrm{K}$ & 9.02 & 9.08 \\
\hline \multicolumn{3}{|c|}{} \\
$\mathrm{Fe}$ & 0.97 & 0.86 \\
\hline $\mathrm{Mn}$ & 1.32 & 1.35 \\
\hline $\mathrm{Zn}$ & 0.72 & 0.78 \\
\hline
\end{tabular}

The compost manure (COM) was prepared according to Nasef et al. (2009) using some crop residues (rice straw, maize stover and faba bean straw). The final product was chemically analyzed according to Brunner and Wasmer (1978). The chemical compositions of the used organic amendments are shown in Table 3.

Table 3. Some chemical characteristics of the organic amendments used in the current study

\begin{tabular}{|c|c|c|c|c|c|c|c|c|c|c|c|}
\hline \multirow[t]{2}{*}{$\begin{array}{l}\text { Organic } \\
\text { amendment }\end{array}$} & \multirow[t]{2}{*}{$\mathbf{p H}$} & \multirow{2}{*}{$\begin{array}{c}\text { EC } \\
\left(\mathrm{dSm}^{-1}\right) \\
(1: 10)\end{array}$} & \multirow[t]{2}{*}{$\begin{array}{l}\text { O.C } \\
(\%)\end{array}$} & \multirow[t]{2}{*}{$\begin{array}{l}\text { O.M } \\
(\%)\end{array}$} & \multirow[t]{2}{*}{$\begin{array}{c}\mathbf{C} / \mathbf{N} \\
\text { ratio }\end{array}$} & \multicolumn{3}{|c|}{$\begin{array}{c}\text { Available } \\
\text { macronutrients } \\
(\%)\end{array}$} & \multicolumn{3}{|c|}{$\begin{array}{c}\text { Available } \\
\text { micronutrients } \\
\left(\mathrm{mg} \mathrm{kg}^{-1}\right)\end{array}$} \\
\hline & & & & & & $\mathbf{N}$ & $\mathbf{P}$ & $\mathrm{K}$ & $\mathrm{Fe}$ & Mn & $\mathrm{Zn}$ \\
\hline $\mathrm{YYM}$ & 7.05 & 2. & 22.43 & 8.67 & 10.48 & 2.14 & 0.85 & 2.55 & 358 & 98 & 140 \\
\hline $\mathrm{COM}$ & 5 & 2.7 & 19.25 & 33.19 & 10.24 & 1.88 & 0.63 & 2.29 & 323 & 10 & 132 \\
\hline TR & 7.92 & 3.22 & 24.13 & 41.59 & 14.53 & 1.66 & 0.29 & 2.66 & 314 & 169 & 98 \\
\hline
\end{tabular}

Each of the organic amendments (COM, FYM and TR) was added and mixed thoroughly with soil three weeks before seeding.

Grains of maize (Zea mays cv. Triple hybrid 310) supplied by Maize Department, Field Crop Res Inst. ARC, were sown on $5^{\text {th }}$ and $7^{\text {th }}$ of May 2013 and 2014, respectively.

The treatments were arranged in a randomized complete block design with three replicates. The plot area was $50 \mathrm{~m}^{2}(5 \mathrm{~m}$ width and $10 \mathrm{~m}$ length) and included 20 rows $50 \mathrm{~cm}$ apart, two plants hill ${ }^{-1}$ and $20 \mathrm{~cm}$ between hills.. All plots of the experiment were fertilized with the recommended rates of $P$ and $K$ as follows: $31 \mathrm{~kg} \mathrm{Pha}^{-1}$ as calcium superphosphate $\left(67.6 \mathrm{~g} \mathrm{P} \mathrm{kg}^{-1}\right)$ during seedbed preparation and potassium was added at a rate of $198 \mathrm{~kg} \mathrm{~K}^{-1}$ as potassium sulphate $\left(400 \mathrm{~g} \mathrm{~K} \mathrm{~kg}^{-1}\right)$ in two equal splits 30 and 45 days after seeding. Agricultural practices for growing maize were carried out as recommended by the Ministry of Agriculture, Egypt.

Nitrogen fertilizer was applied as urea, $\left(460 \mathrm{~g} \mathrm{~N} \mathrm{~kg}^{-1}\right)$ at four rates 0 , 60,90 and $120 \mathrm{~kg} \mathrm{~N}$ fed. $^{-1}$ corresponding to $0,143,215$ and $286 \mathrm{~kg} \mathrm{~N} \mathrm{ha}^{-1}$, respectively in three equal doses; started just before planting, then 30 and 50 days after planting. 
The experimental treatments were as follow:

1-Compost manure, COM (5 Mega gram, (Mg) fed. ${ }^{-1}$ i.e.12 $\mathrm{Mg} \mathrm{ha}^{-1}$ ), Mega gram $=10^{6}$ gram $=$ Metric ton

$2-\mathrm{COM}+\mathrm{N}_{0},\left(0 \mathrm{~kg} \mathrm{~N}\right.$ fed $\left.{ }^{-1}\right)$

$3-\mathrm{COM}+\mathrm{N}_{60}$, urea $\left(60 \mathrm{~kg} \mathrm{~N}\right.$ fed. ${ }^{-1}$ i.e. $\left.143 \mathrm{~kg} \mathrm{ha}^{-1}\right)$

$4-\mathrm{COM}+\mathrm{N}_{90}$, urea $\left(90 \mathrm{~kg} \mathrm{~N}\right.$ fed. ${ }^{-1}$ i.e. $\left.215 \mathrm{~kg} \mathrm{ha}^{-1}\right)$

$5-\mathrm{COM}+\mathrm{N}_{120}$, urea $\left(120 \mathrm{~kg} \mathrm{~N}\right.$ fed. $^{-1}$ i.e. $\left.286 \mathrm{~kg} \mathrm{ha}^{-1}\right)$

6-Town refuse manure, TR ( $5 \mathrm{Mg}$ fed. $^{-1}$ i.e. $\left.12 \mathrm{~kg} \mathrm{ha}^{-1}\right)$

$7-\mathrm{TR}+\mathrm{N}_{0} \quad 8-\mathrm{TR}+\mathrm{N}_{60} \quad 9-\mathrm{TR}+\mathrm{N}_{90} \quad 10-\mathrm{TR}+\mathrm{N}_{120}$

11-Farmyard manure, FYM (5 Mg fed. ${ }^{-1}$ i.e. $12 \mathrm{Mg} \mathrm{ha}^{-1}$ )

$12-\mathrm{FYM}+\mathrm{N}_{0} \quad 13-\mathrm{FYM}+\mathrm{N}_{60}$

$14-\mathrm{FYM}+\mathrm{N}_{90} \quad 15-\mathrm{FYM}+\mathrm{N}_{120}$

At maturity, maize ears were collected on the $20^{\text {th }}$ October from each plot, counted and weighed. At harvesting stage, grains and cobs were weighed, 100 grain weight was recorded. Total chlorophyll content was estimated in fresh leaves as described by Witham et al. (1971). Total proline content was estimated according to the method described by Bates et al. (1973).

The agronomic characters i.e. plant height $(\mathrm{cm})$, weight of grains ear ${ }^{-1}$ (g), 100-grain weight (g) and grain yield ( $\left.\mathrm{Mg} \mathrm{fed}^{-1}\right)$.

\section{Methods of analyses}

\section{Soil analysis}

Particle size distribution was carried out according to Piper (1950). EC (in soil paste extract), $\mathrm{pH}$ (in 1: 2.5 soil: water suspension), organic matter content and $\mathrm{CaCO}_{3}$ content were determined according to Page et al. (1982). Available nitrogen was extracted by $\mathrm{KCl} 2 \mathrm{~N}$ extractant and determined by steam distillation procedure using $\mathrm{MgO}$ - Devarda alloy according to Bremner and Keeney methods as described by Black et al. (1965). Available phosphorus was extracted using $0.5 \mathrm{M} \mathrm{Na} \mathrm{HCO}$ solutionat pH 8.5 and determined colorimetrically according to Page et al (1982). Available potassium was extracted using $1 \mathrm{~N}$ ammonium acetate at pH 7.0 and determined photometrically according to Jackson (1958). Available iron, manganese and zinc were extracted by DTPA as described by Soltanpour, (1985). and measured using atomic absorption spectrophotometer.

\section{Plant analyses}

Maize seeds were oven dried at $70 \mathrm{C}^{\circ}$ then digested using a mixture of $\mathrm{H}_{2} \mathrm{SO}_{4}$ and $\mathrm{HClO}_{4}$ acids. The macro and micronutrients were determined in the digest according to the Ryan et al. (1996). Total chlorophyll was determined according to Saric et al. (1967). Total proline content was determined according to Bates et al. (1973). The macro and micro-nutrients were determined as mentioned before.

The following parameters were calculated:

$>$ Grain protein contents by multiplying N\% of grains by 6.25 (FAO, 2003).

$>$ Grain protein yield in $\mathrm{kg} \mathrm{ha}^{-1}$ \{protein content $\mathrm{g} \mathrm{kg}^{-1} \times$ grain yield $\mathrm{Mg}$ fed. ${ }^{-1}$ \}

$>$ Apparent $\mathrm{N}$ recovery (ANR) by the equation described by Echeverria and Videla (1998), [N uptake of plant (fertilized plot) - N uptake (zero plot) / $\mathrm{N}$ fertilizer rate] $X 100$. 
$>$ Nitrogen agronomic efficiency (NAE) according to Craswell and Godwin (1984): [grain yield of (fertilized plot) - grain yield (zero plot)] / $N$ fertilizer rate yield and $\mathrm{N}$ fertilizer in $\mathrm{kg}_{\text {fed. }}{ }^{-1}$.

$>$ Nitrogen use efficiency (NUE) was calculated as the amount of grain yield per unit of applied $\mathrm{N}$ ( $\mathrm{kg}$ of grain yield $\mathrm{kg}^{-1}$ of $\mathrm{N}$ applied) as described by Angas et al. (2006).

Statistical analysis

Data were subjected to statistical analysis of variance (ANOVA), and the least significant differences (L.S.D) at 5\% level according to Snedecor and Cochran, (1971).

\section{RESULTS AND DISCUSSION}

\section{Effect of treatments on growth parameters and yield of maize: Growth parameters}

Growth parameters of maize plants are shown in Table 4, revealed that application of the organic amendments increased significantly plant height and grain weight per ear. Application of $\mathrm{N}$ affected significantly all the studied growth parameters. However, the weight of 100 grain (g) was not affected significantly by source of the organic amendment in both the growing seasons. Mean values of plant height achieved due to treating soil with COM was significantly higher than the corresponding ones achieved due to TR. Also, the differences between the values of plant height attained due to COM and FYM were significant but, on the other hand, no significant difference was shown between mean values of plant height achieved due to TR and FYM. This occurred in both seasons of growing maize plant. Grain weight ear $^{-1}$ was affected by the used treatments in a way almost typical to that by which plant height was affected. The highest values of plant height, grain weight per ear and 100-grain weight were recorded for the plants treated with $\mathrm{FYM}+\mathrm{N}_{120}$ which caused respective increases of about $33.9 \%, 21.2 \%$ and $7.0 \%$ in 2013 season corresponding to $38.6 \%, 22.9 \%$ and $7.9 \%$, respectively in 2014 season. The applied $\mathrm{N}$ might enhanced the organic matter decomposers which in turn, provided more suitable conditions for release of the nutrients in available form. On the other hand, the interaction between source of the applied amendment and rate of the applied $\mathrm{N}$ seemed to be significant effect on all the studied growth parameters in the first season but was significant effect only on plant height in the second growing season. This finding stands in well agreement with that of Abedi et al. (2010) and Daneshmand et al. (2012).

Grain yield:

As shown in Table 4, both organic amendments and rate of the applied $\mathrm{N}$ fertilizer significantly increased grain yield of maize plants in both growing seasons. The organic amendments followed the following descending order according to their effects on grain yield: FYM > TR > CO M. This trend was found to be true for both the two growing seasons. The organic manure content of the nutritive elements and the reduction in soil $\mathrm{pH}$ due to decomposition of the organic amendments beside of dissolution of $\mathrm{CO}_{2}$ 
resulting from the exhalation of the organic matter decomposers facilitated release of nutritive elements in forms more available for uptake by maize and hence increased maize grain yield. This result is in agreement with Hegazi (2004), Joshi et al. (2012), Berhanu et al. (2013) and Namvar and Teymur (2013).

Table 4. yield and yield components of maize plant as affected by organic amendments in combinations with urea

\begin{tabular}{|c|c|c|c|c|c|}
\hline Organic amendment (S) & $\begin{array}{c}\text { Rate of N } \\
\left.\text { (kg fed. }^{-1}\right) \\
\text { (R) }\end{array}$ & $\begin{array}{c}\text { Plant } \\
\text { height } \\
\text { (cm) }\end{array}$ & $\begin{array}{c}\text { Grain } \\
\text { weight } \\
\text { ear }^{-1}\end{array}$ & $\begin{array}{l}100 \text { - grain } \\
\text { weight }(\mathrm{g})\end{array}$ & $\begin{array}{l}\text { Grain yield } \\
\text { (Mg fed. }^{-1} \text { ) }\end{array}$ \\
\hline \multicolumn{6}{|c|}{ First season (2013) } \\
\hline \multirow{4}{*}{ COM } & $\mathrm{N}_{0}$ & 120 & 89.56 & 31.52 & 1.28 \\
\hline & $\mathrm{N}_{60}$ & 142 & 92.40 & 32.64 & 1.59 \\
\hline & $\mathrm{N}_{90}$ & 158 & 99.48 & 32.85 & 1.86 \\
\hline & $\mathrm{N}_{120}$ & 162 & 99.79 & 33.01 & 1.88 \\
\hline \multicolumn{2}{|l|}{ Mean } & 146 & 95.31 & 32.51 & 1.65 \\
\hline \multirow{4}{*}{ TR } & $\mathrm{N}_{0}$ & 123 & 90.14 & 31.76 & 1.32 \\
\hline & $\mathrm{N}_{60}$ & 147 & 97.63 & 32.88 & 1.69 \\
\hline & $\mathrm{N}_{90}$ & 163 & 104.66 & 33.19 & 1.98 \\
\hline & $\mathrm{N}_{120}$ & 165 & 108.32 & 33.69 & 2.04 \\
\hline \multicolumn{2}{|l|}{ Mean } & 150 & 100.19 & 32.88 & 1.76 \\
\hline \multirow{4}{*}{ FYM } & $\mathrm{N}_{0}$ & 127 & 91.47 & 31.96 & 1.32 \\
\hline & $\mathrm{N}_{60}$ & 152 & 98.43 & 32.45 & 1.75 \\
\hline & $\mathrm{N}_{90}$ & 163 & 107.00 & 33.66 & 2.03 \\
\hline & $\mathrm{N}_{120}$ & 170 & 110.85 & 34.18 & 2.08 \\
\hline \multicolumn{2}{|l|}{ Mean } & 153 & 101.94 & 33.06 & 1.80 \\
\hline \multirow{3}{*}{ LSD 0.05} & $\mathrm{R}$ & 3.49 & 2.46 & 0.94 & 0.024 \\
\hline & $\mathrm{S}$ & 3.02 & 2.13 & ns & 0.021 \\
\hline & $\mathrm{R} \times \mathrm{S}$ & ns & ns & ns & ** \\
\hline \multicolumn{6}{|c|}{ Second season (2014) } \\
\hline \multirow{4}{*}{ COM } & $\mathrm{N}_{0}$ & 121 & 92.41 & 31.88 & 1.32 \\
\hline & $\mathrm{N}_{60}$ & 140 & 99.38 & 32.69 & 1.96 \\
\hline & $\mathrm{N}_{90}$ & 158 & 104.58 & 32.87 & 2.04 \\
\hline & $\mathrm{N}_{120}$ & 165 & 109.34 & 33.15 & 2.09 \\
\hline \multicolumn{2}{|l|}{ Mean } & 146 & 101.43 & 32.65 & 1.85 \\
\hline \multirow{4}{*}{ TR } & $\mathrm{N}_{0}$ & 125 & 92.88 & 31.95 & 1.33 \\
\hline & $\mathrm{N}_{60}$ & 149 & 105.41 & 32.98 & 1.97 \\
\hline & $\mathrm{N}_{90}$ & 164 & 109.63 & 33.52 & 2.08 \\
\hline & $\mathrm{N}_{120}$ & 172 & 112.74 & 33.75 & 2.13 \\
\hline \multicolumn{2}{|l|}{ Mean } & 153 & 105.17 & 33.05 & 1.88 \\
\hline \multirow{4}{*}{ FYM } & $\mathrm{N}_{0}$ & 127 & 93.01 & 32.01 & 1.34 \\
\hline & $\mathrm{N}_{60}$ & 159 & 108.37 & 33.98 & 1.99 \\
\hline & $\mathrm{N}_{90}$ & 168 & 112.98 & 34.25 & 2.12 \\
\hline & $\mathrm{N}_{120}$ & 176 & 114.30 & 34.55 & 2.18 \\
\hline \multicolumn{2}{|l|}{ Mean } & 158 & 107.17 & 33.70 & 1.91 \\
\hline \multirow{3}{*}{ LSD $_{0.05}$} & $\mathrm{R}$ & 2.48 & 2.12 & 1.08 & 0.014 \\
\hline & $S$ & 2.15 & 1.83 & ns & 0.012 \\
\hline & $\mathrm{R} \times \mathrm{S}$ & * & ns & ns & ns \\
\hline
\end{tabular}


The interaction effect between organic amendments sources and rate of the applied $\mathrm{N}$ although was of highly significant effect on the grain yield in the first season, yet such a relation was insignificant in the second one.

\section{Protein content of grains:}

It can be seen from results presented in Fig. 1 that the grain protein content increased due to application of both organic amendments and $\mathrm{N}$ fertilizer. The highest values of protein content $\left(101\right.$ and $\left.103 \mathrm{~g} \mathrm{~kg}^{-1}\right)$ were obtained due to the treatment TR $+\mathrm{N}_{120}$ in 2013 and 2014 seasons representing increase percentages of $9.90 \%$ and $9.81 \%$, respectively. The favorable effect of mineral $\mathrm{N}$-fertilization is attributed to its role as one of the most important constituents of all proteins and nucleic acids, and hence protoplasm and chlorophyll (Wortman et al. 2011). As the level of $\mathrm{N}$ - supply increases, the extra protein produced allows the plant leaves to grow larger and consequently photosynthesis increases; therefore, the increase in $\mathrm{N}$ fertilization level led to an increase in metabolic processes and physiological activities necessary for more plant organs formation, more dry matter accumulation and enhancing the grain hilling rate, which finally increased the amount of protein in grain. These results are in accordance with those reported by Poraas et al. (2008), Abbas et al. (2011) and Joshi et al. (2012). TR was more superior on protein content of grains than both COM and FYM especially, at the highest rate of applied $\mathrm{N}$ fertilizer $\left(\mathrm{N}_{120}\right)$.

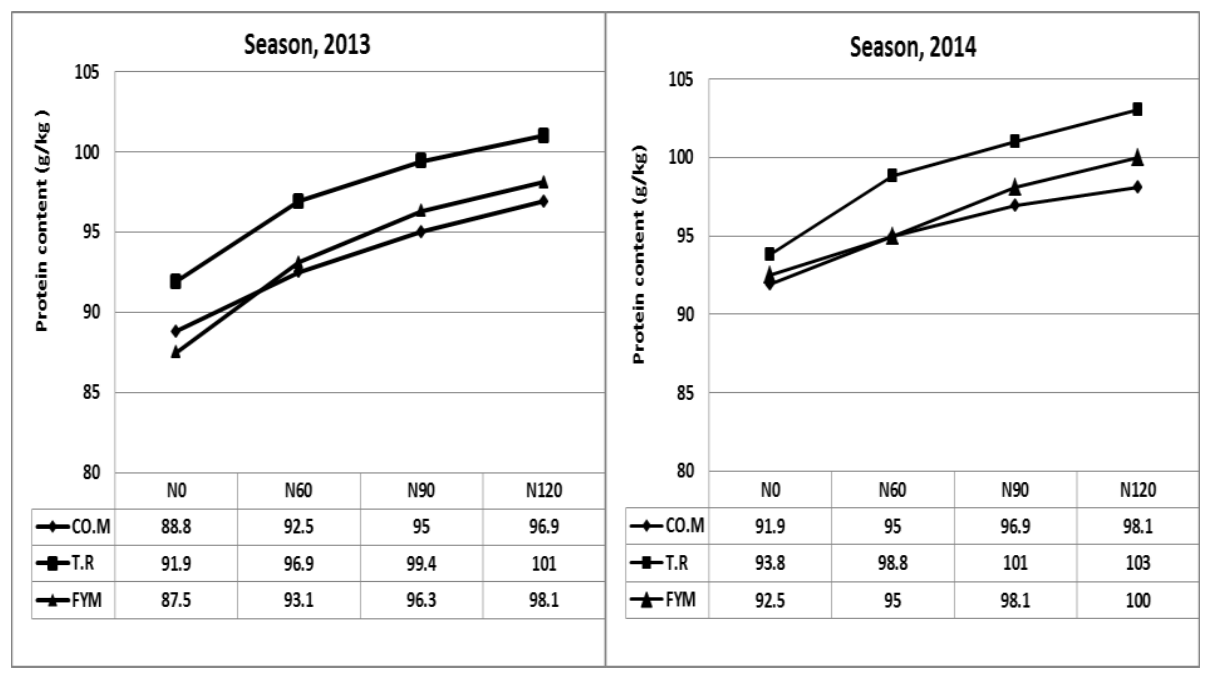

Fig 1. Protein content $\left(\mathrm{g} \mathrm{kg}^{-1}\right)$ as affected by the applied organic amendments and urea fertilizer

Total proline and chlorophyll contents:

Fig. 2 shows that the plants received organic amendments and urea showed significant proline decreases compared to those received organic amendments only. However, the used organic amendments can be arranged due to their effects on decreasing proline content in the following descending order: $\mathrm{TR}>\mathrm{FYM}>\mathrm{COM}$. 

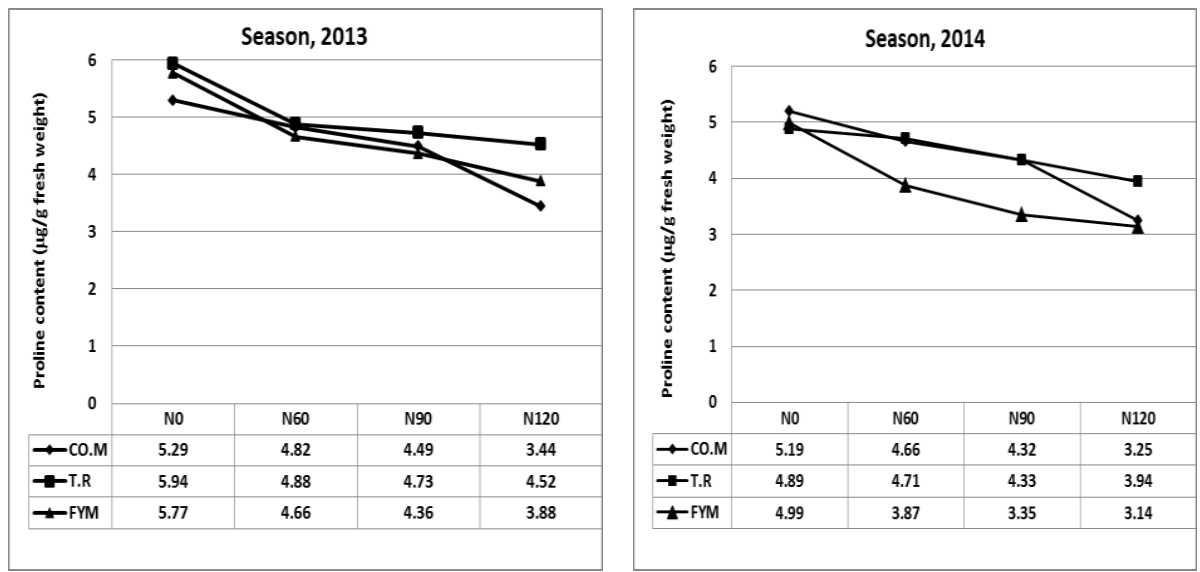

Fig 2. Proline content ( $\square \mathrm{g} \mathrm{g}^{-1}$ fresh weight of maize leaves) as affected by organic amendments in combination with urea.

The rate of applied mineral $\mathrm{N}$ seemed, generally, inversely related to proline content. Nour EI-Din and Salama (2006) reported that proline accumulation is a common metabolic response of higher plants to salinity stress. Also, compost treatments decreased the proline accumulation in wheat plants grown in saline soil. These results agree with those obtained by Amirjani (2011) and Siam et al. (2013).

As for chlorophyll content, it can be seen from results illustrated in Fig.3 that the chlorophyll content significantly increased due to applying organic amendments solely or together with $\mathrm{N}$. The increases occurred in chlorophyll content followed the descending order: COM $>$ FYM $>$ TR and $N_{120}>N_{90}>N_{60}$ in both 2013 and 2014 seasons. The highest chlorophyll content values (89.1 and $89.4 \mathrm{mg} \mathrm{kg}^{-1}$ fresh weight) were attained due to $\mathrm{COM}+\mathrm{N}_{120}$ in both seasons of study.
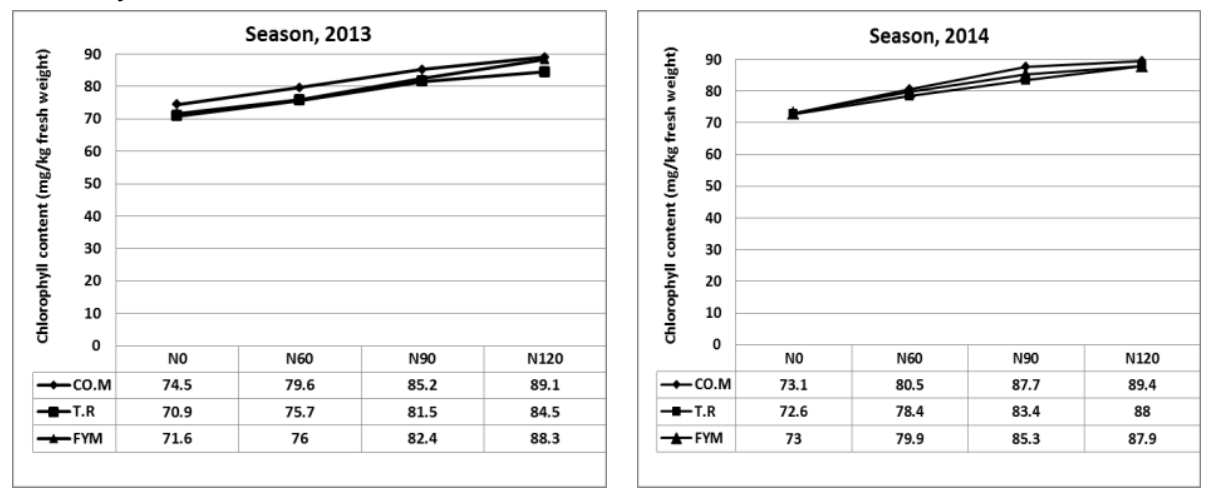

Fig 3. Chlorophyll content ( $\mathrm{mg} \mathrm{kg}^{-1}$ fresh weight of maize leaves) as affected by organic in combined with urea. 


\section{Macronutrient (NPK) contents in grains:}

Data in Table 5 show that uptake values of $\mathrm{N}, \mathrm{P}$ and $\mathrm{K}$ contents in grains generally increased significantly due to increasing rate of applied $\mathrm{N}$. The applied organic amendments were, on the other hand, of no significant effect on $\mathrm{P}$ and $\mathrm{K}$. Only, $\mathrm{N}$ content increased significantly due to these amendments which followed according to their effects on $\mathrm{N}$ content the following descending order: TR > FYM $>\mathrm{COM}$. This promoting effect could be related to the $\mathrm{N}$ supplementary effect of microorganisms on plants due to their ability to fix free molecular atmospheric nitrogen as well as the role of these bacteria in improving the availability of soil elements through secreting organic acids which enhance availability and $\mathrm{N}$ uptake (Kandil et al., 2011 and Daneshmand et al., 2012). Meanwhile, the organic manures might create favorable soil physical and chemical conditions, which affect the solubility and availability of nutrients and their uptake values. (Diacono et al., 2013). These results coincide with the results of Abbas et al. (2011) and Namvar and Teymur (2013).

The investigated amendments can be arranged according to their effects on P uptake in the following descending order: FYM > TR > COM.

This order was found to be true whether the organic amendments were applied solely or in combination with $\mathrm{N}$. K-uptake was not significantly affected by the addition of organic sources in the first season, whereas such an effect was significant in the second one. The production of organic acids during the degradation of such organic materials as a result of the microorganism's activities must have decreased soil $\mathrm{pH}$ which would increase $\mathrm{K}$ availability for plant uptake. Moreover, application of the organic amendments would result in more favorable soil physical conditions for $\mathrm{K}$ uptake by plants (Rabie et al., 1997). These results are in agreement with those obtained by El-Sherbieny et al. (1999) and Mohamed (2002). The interaction between source of the organic amendments and rate of applied $\mathrm{N}$ did not affect significantly N, P and K uptake by maize plants.

\section{Micronutrient contents in grains}

Values of $\mathrm{Fe}, \mathrm{Mn}$ and $\mathrm{Zn}$ uptake by maize grains as affected by application of organic amendments solely or in combination with urea are shown in Table 5. These values, generally, increased but insignificantly due to increasing rate of the applied $\mathrm{N}$ fertilizer during the first growing seasons. Zn uptake was only the exception in this season. In the second season, uptake values of $\mathrm{Fe}, \mathrm{Mn}$ and $\mathrm{Zn}$ were all significantly affected by increasing rate of the applied $\mathrm{N}$.

Although sources of the applied organic amendments were of insignificant effect on $\mathrm{Fe}, \mathrm{Mn}$ and $\mathrm{Zn}$ uptake values, yet their interaction with rate of the applied $\mathrm{N}$ significantly affected $\mathrm{Mn}$ and $\mathrm{Zn}$ uptake in the first season but, on the other hand, such an effect was insignificant in the second season. However, it was found that the applied organic amendments could increase $\mathrm{Fe}, \mathrm{Mn}$ and $\mathrm{Zn}$ uptake as compared to the control treatment. These results are in line with those of Ashmaye et al. (2008) and Nasef et al. (2009) who reported that the application of compost combined with mineral $\mathrm{N}$ fertilizer caused pronounced increases in soil available micronutrients content under rice cropping. These increases may be attributed to one or more of the following reasons :I) Releasing of these nutrients through microbial decomposition of organic matter ; II) Enhancing the chelation of metal ions by organic legands or other 
organic function groups which may promote the mobility of metal from solid to liquid phase in the soil environment; III) Lowering the redox status of iron and manganese, leading to reduction of $\mathrm{Fe}^{3+}$ and $\mathrm{Mn}^{4+}$ to $\mathrm{Fe}^{2+}$ and $\mathrm{Mn}^{2+}$ and / or transformation of insoluble chelated forms into more soluble ones.

Table 5. Macro and micronutrients content in maize grains as affected by organic amendments in combinations with urea.

\begin{tabular}{|c|c|c|c|c|c|c|c|}
\hline \multirow{2}{*}{$\begin{array}{l}\text { Organic amendment } \\
\text { (S) }\end{array}$} & \multirow{2}{*}{$\begin{array}{l}\text { Rate of } \mathbf{N} \\
\left(\mathrm{kg} \mathrm{fed}^{-1}\right) \\
(\mathrm{R})\end{array}$} & \multicolumn{3}{|c|}{$\begin{array}{l}\text { Macronutrient } \\
\text { content (\%) }\end{array}$} & \multicolumn{3}{|c|}{$\begin{array}{c}\text { Micronutrient } \\
\text { content }\left(\mathrm{mg} \mathrm{kg}^{-1}\right)\end{array}$} \\
\hline & & $\mathbf{N}$ & $\mathbf{P}$ & $\mathbf{K}$ & $\mathrm{Fe}$ & Mn & $\mathrm{Zn}$ \\
\hline \multicolumn{8}{|c|}{ First season (2013) } \\
\hline \multirow{4}{*}{ (COM) } & $\mathrm{N}_{0}$ & 1.42 & 0.36 & 1.89 & 87.36 & 45.96 & 32.19 \\
\hline & $\mathrm{N}_{60}$ & 1.48 & 0.42 & 1.96 & 89.35 & 48.61 & 33.68 \\
\hline & $\mathrm{N}_{90}$ & 1.52 & 0.47 & 1.97 & 90.34 & 49.34 & 35.41 \\
\hline & $\mathrm{N}_{120}$ & 1.55 & 0.52 & 2.04 & 91.55 & 49.88 & 35.86 \\
\hline \multicolumn{2}{|l|}{ Mean } & 1.49 & 0.44 & 1.97 & 90.00 & 48.45 & 34.29 \\
\hline \multirow{4}{*}{ (TR) } & $\mathrm{N}_{0}$ & 1.47 & 0.40 & 1.95 & 87.69 & 46.00 & 32.88 \\
\hline & $\mathrm{N}_{60}$ & 1.55 & 0.44 & 1.99 & 90.27 & 49.88 & 34.12 \\
\hline & $N_{90}$ & 1.59 & 0.48 & 2.03 & 91.66 & 51.37 & 37.00 \\
\hline & $N_{120}$ & 1.62 & 0.54 & 2.06 & 92.10 & 52.96 & 37.52 \\
\hline \multicolumn{2}{|l|}{ Mean } & 1.56 & 0.47 & 2.01 & 90.00 & 50.05 & 35.38 \\
\hline \multirow{4}{*}{ (FYM) } & $\mathrm{N}_{0}$ & 1.45 & 0.43 & 1.98 & 88.00 & 45.89 & 32.98 \\
\hline & $\mathrm{N}_{60}$ & 1.49 & 0.49 & 2.04 & 90.88 & 48.95 & 33.85 \\
\hline & $\mathrm{N}_{90}$ & 1.54 & 0.55 & 2.07 & 92.03 & 49.74 & 36.29 \\
\hline & $\mathrm{N}_{120}$ & 1.57 & 0.57 & 2.10 & 92.47 & 51.33 & 36.67 \\
\hline \multicolumn{2}{|l|}{ Mean } & 1.51 & 0.51 & 2.05 & 91.00 & 48.98 & 34.95 \\
\hline \multirow{3}{*}{ LSD $_{0.05}$} & $\mathrm{R}$ & 0.051 & 0.031 & 0.027 & ns & ns & 1.47 \\
\hline & $\mathrm{S}$ & 0.044 & $\mathrm{~ns}$ & ns & ns & ns & ns \\
\hline & $\mathrm{R} \times \mathrm{S}$ & ** & ** & ** & $\mathrm{ns}$ & ** & ** \\
\hline \multicolumn{8}{|c|}{ Second season (2014) } \\
\hline \multirow{4}{*}{ (CO.M) } & $\mathrm{N}_{0}$ & 1.47 & 0.39 & 1.92 & 88.14 & 46.35 & 33.05 \\
\hline & $\mathrm{N}_{60}$ & 1.52 & 0.45 & 1.98 & 91.00 & 49.55 & 35.69 \\
\hline & $\mathrm{N}_{90}$ & 1.55 & 0.49 & 2.03 & 91.49 & 50.78 & 36.72 \\
\hline & $N_{120}$ & 1.57 & 0.53 & 2.06 & 91.86 & 51.44 & 37.46 \\
\hline \multicolumn{2}{|l|}{ Mean } & 1.53 & 0.47 & 2.00 & 91.00 & 49.53 & 35.73 \\
\hline \multirow{4}{*}{ (TR) } & $\mathrm{N}_{0}$ & 1.50 & 0.45 & 1.97 & 88.37 & 46.97 & 34.29 \\
\hline & $N_{60}$ & 1.58 & 0.49 & 2.03 & 91.42 & 51.63 & 37.55 \\
\hline & $\mathrm{N}_{90}$ & 1.61 & 0.54 & 2.06 & 92.87 & 54.98 & 38.64 \\
\hline & $N_{120}$ & 1.65 & 0.58 & 2.09 & 95.37 & 55.01 & 39.15 \\
\hline \multicolumn{2}{|l|}{ Mean } & 1.59 & 0.52 & 2.04 & 92.00 & 52.15 & 37.41 \\
\hline \multirow{4}{*}{ (FYM) } & $\mathrm{N}_{0}$ & 1.48 & 0.48 & 2.01 & 88.64 & 48.00 & 33.65 \\
\hline & $N_{60}$ & 1.52 & 0.55 & 2.07 & 91.42 & 49.76 & 36.52 \\
\hline & $\mathrm{N}_{90}$ & 1.57 & 0.59 & 2.12 & 93.48 & 50.73 & 36.95 \\
\hline & $N_{120}$ & 1.60 & 0.62 & 2.15 & 93.56 & 53.14 & 37.77 \\
\hline \multicolumn{2}{|l|}{ Mean } & 1.54 & 0.56 & 2.09 & 92.00 & 50.41 & 36.22 \\
\hline \multirow{3}{*}{ LSD $_{0.05}$} & $\mathrm{R}$ & 0.030 & 0.027 & 0.025 & 1.72 & 3.10 & 1.54 \\
\hline & $S$ & 0.026 & 0.023 & 0.022 & ns & ns & 1.33 \\
\hline & $R \times S$ & ns & ns & ns & ns & ns & ns \\
\hline
\end{tabular}




\section{Effect of the treatments on $\mathrm{N}$ utilization efficiencies}

The efficiency of applied $\mathrm{N}$ is considered important criterion beside the $\mathrm{N}$ requirements to obtain maximum economic yield. Accordingly, the efficiencies of the applied nitrogen for the different organic and mineral $\mathrm{N}$ treatments were calculated and the results are shown in Table 6.

Nitrogen use efficiency (NUE) $\mathbf{~ g ~ k ~}^{-1}$

Values of the nitrogen use efficiency (NUE) were higher upon addition of the organic amendments solely than upon their addition combined with either of the studied $\mathrm{N}$ rates. On the other hand, application of nitrogen in combination with any of the investigated organic amendments decreased NUE obviously, probably because nitrogen of the organic amendments was less available for plant uptake than the applied mineral nitrogen. These results are in line with those obtained by Abbas et al. (2011) who found that the values of NUE markedly decreased as the nitrogen addition rate increased. Values of NUE ranged from $8.79-15.90$ at 2013 season and $9.77-16.02$ at the second season 2014.

The highest NUE value $16.02 \mathrm{~kg} \mathrm{~kg}^{-1}$ was obtained at the second growing season when plants were treated with TR without urea $\mathrm{N}_{0}$. Generally, the studied organic amendments can be arranged according to their effects on NUE in the following descending order: TR > COM > FYM.

Table 6. Nitrogen use efficiency (NUE), apparent $\mathrm{N}$ recovery ANR and Nitrogen agronomic efficiency (NAE) of maize as influenced by organic amendments and urea

\begin{tabular}{|c|c|c|c|c|c|c|c|c|c|c|c|c|}
\hline \multirow[t]{3}{*}{ Season } & \multicolumn{4}{|c|}{ COM } & \multicolumn{4}{|c|}{ TR } & \multicolumn{4}{|c|}{ FYM } \\
\hline & \multicolumn{12}{|c|}{$\mathrm{N}$ addition rate $\left(\mathrm{kg} \mathrm{N}\right.$ fed $\left.^{-1}\right)$} \\
\hline & 0 & 60 & 90 & 120 & 0 & 60 & 90 & 120 & 0 & 60 & 90 & 120 \\
\hline \multicolumn{13}{|c|}{ Nitrogen use efficiency, NUE $\left(\mathrm{kg} \mathrm{kg}^{-1} \mathrm{~N}\right)$} \\
\hline 2013 & 13.62 & 10.33 & 10.11 & 8.79 & 15.90 & 11.82 & 11.45 & 10.05 & 12.34 & 10.48 & 10.31 & 9.16 \\
\hline 2014 & 14.04 & 13.00 & 11.09 & 9.77 & 16.02 & 13.78 & 12.02 & 10.49 & 12.52 & 11.92 & 10.76 & 9.60 \\
\hline \multicolumn{13}{|c|}{ Nitrogen agronomic efficiency, $\mathrm{NAE}\left(\mathrm{kg} \mathrm{kg}^{-1} \mathrm{~N}\right)$} \\
\hline 2013 & 0.00 & 2.00 & 4.00 & 2.80 & 0.00 & 2.59 & 4.00 & 3.55 & 0.00 & 2.58 & 3.60 & 3.35 \\
\hline 2014 & 0.00 & 5.00 & 3.91 & 3.60 & 0.00 & 4.48 & 4.34 & 3.94 & 0.00 & 3.83 & 3.96 & 3.70 \\
\hline \multicolumn{13}{|c|}{ Apparent nitrogen recovery, ANR (\%) } \\
\hline 2013 & 0.00 & 3.47 & 5.48 & 5.12 & 0.00 & 4.76 & 6.98 & 6.73 & 0.00 & 4.16 & 6.15 & 5.96 \\
\hline 2014 & 0.00 & 6.75 & 6.64 & 6.27 & 0.00 & 7.82 & 7.83 & \begin{tabular}{|l|l|}
7.49 \\
\end{tabular} & 0.00 & 6.24 & 6.83 & 6.63 \\
\hline
\end{tabular}

\section{Apparent nitrogen recovery (ANR)}

The ANR parameter, which indicates the ability to increase $\mathrm{N}$ uptake in response to $\mathrm{N}$ applied and the proportions of fertilizer $\mathrm{N}$ recovered by the plants, was greatest when $90 \mathrm{~kg} \mathrm{~N} \mathrm{fed}^{-1}$ was added in combination with TR where its values were $6.98 \%$ and $7.83 \%$ in the two growing seasons 2013 and 2014, respectively. This shows that the application of the medium rate of nitrogen caused an enhancing effect on plant growth. The lowest $\mathrm{N}$ recovery occurred at the rate of $\mathrm{N}_{60}$. The lower $\mathrm{N}$ recovery due to compost $+\mathrm{N}_{60}$ treatment occurred due to lower $\mathrm{N}$ uptake by grains compared to the other treatments. 


\section{Nitrogen agronomic efficiency (NAE) $\mathbf{k g ~ k g}^{-1}$.}

The NAE parameter (the plant ability to increase the yield in response to $\mathrm{N}$ fertilization level) ( $\mathrm{kg}$ grain / $\mathrm{kg} \mathrm{N}$ applied) followed the same trend shown for apparent nitrogen recovery (ANR) hence, the increase of $\mathrm{N}$ rate decreased the NAE values. The highest NAE value $\left(5.00 \mathrm{~kg} \mathrm{~kg}^{-1}\right.$ at 2014 season) was obtained due to the treatment $\mathrm{COM}+\mathrm{N}_{60}$ which resulted in 38.9 percentage increase in 2014 season compared with the treatment $\mathrm{N}_{120}$.

\section{Effect of treatments on some soil chemical properties after maize harvest Soil pH and EC}

Data in Table 7 show the effects of the studied organic amendments with or without $\mathrm{N}$ - fertilizer on some chemical properties of the soil under study at the end of the experimental work. The values of $\mathrm{pH}$ were slightly decreased as affected by all the studied treatments. These results are in agreement with those of Siam et al. (2013) who reported that the decrease in $\mathrm{pH}$ was marked particularly when $\mathrm{N}$ and compost fertilization were combined. The highest decrease in $\mathrm{pH}$ value was achieved due to treating the soil with $\mathrm{FYM}+\mathrm{N}_{120}$. Such decreases in soil pH might be attributed to the effect of microorganisms on decomposing organic matter which released organic acids beside of producing several phytohormones such as indole acetic acid and cytokinins. These results are similar to those obtained by Ashmaye et al. (2008) and Abdel-Fattah (2012).

The EC values decreased when the organic amendments were applied with or without combination of $\mathrm{N}$-fertilizer. Improvement in porosity and aggregation probably occurred due to the applied amendments. Thus, organic amendments enhanced the leaching of salts and reduced EC values (Zaka et al., 2005). The reclamation pre-treatments executed before carrying out the experiment might contributed together with the applied amendments to modification of soil physical properties, especially soil structure as well as soil aggregation, drainable pores and permeability of soil and therefore encouraged downward movement of water carrying soluble salts out of the soil. These results are in agreement with those of Bassiouny and Shaban (2010) and Rashed et al. (2011).

However, the lowest EC values (6.29 and $\left.5.48 \mathrm{dSm}^{-1}\right)$ were recorded with the treatment of $\mathrm{COM}+\mathrm{N}_{120}$ in both seasons of study. The used treatments could be arranged according to their effects on reducing $E C$ of soil in the following descending order: COM > FYM > TR when added solely or in combination with $\mathrm{N}$. This trend was found true for the two seasons. These results are in agreement with those obtained by Nasef et al. (2009) who reported that compost application facilitated leaching of soluble salts and decreased soil salinity.

Available macronutrients ( $N, P$ and $K$ ) in soil.

Data presented in Table 7 show the available contents of N, P and $K$ $\left(\mathrm{mg} \mathrm{kg}^{-1}\right)$ in soil as affected by the used treatments. Available N, P and K increased as affected by the organic amendments solely or with $\mathrm{N}$ fertilization. The soil treated with compost $+N_{120}$ gave the highest values of available N, P and $\mathrm{K}$ in both the two seasons. The positive effect of organic amendments is partially due to a slow release of their contents of $\mathrm{N}$, 
(Bhandari et al. 2002). The $\mathrm{P}$ and $\mathrm{K}$ fractions added through organic amendments upon their decomposition with time may account for the increases in both $\mathrm{P}$ and $\mathrm{K}$. (Yadvinder et al., 2004). Also, the production of organic and inorganic acids during the degradation of such organic materials must have contributed to a decrease in soil $\mathrm{pH}$ and hence increased available forms of elements in the rhizosphere zone. These results are in agreement with those obtained by Ewees and Abdel Hafeez (2010).

Table 7. $\mathrm{pH}, \mathrm{EC}\left(\mathrm{dSm}^{-1}\right)$, macro and micronutrient available contents in soil after maize harvest.

\begin{tabular}{|c|c|c|c|c|c|c|c|c|c|}
\hline \multirow{2}{*}{$\begin{array}{l}\text { Organic } \\
\text { source (S) }\end{array}$} & \multirow{2}{*}{$\begin{array}{c}\text { Rate of } \mathbf{N} \\
\left.\text { (kg fed.- }^{-1}\right) \\
(R)\end{array}$} & \multirow{2}{*}{$\begin{array}{c}\text { pH } \\
(1: 2.5)\end{array}$} & \multirow{2}{*}{$\begin{array}{c}E C \\
\left(d \mathrm{Sm}^{-1}\right)\end{array}$} & \multicolumn{3}{|c|}{$\begin{array}{l}\text { Macronutrients } \\
\left(\mathrm{mg} \mathrm{kg}^{-1}\right)\end{array}$} & \multicolumn{3}{|c|}{$\begin{array}{l}\text { Micronutrients } \\
\left(\mathrm{mg} \mathrm{kg}^{-1}\right)\end{array}$} \\
\hline & & & & $\mathbf{N}$ & $\mathbf{P}$ & $\mathbf{K}$ & $\mathrm{Fe}$ & Mn & Zn \\
\hline \multicolumn{10}{|c|}{ First season (2013) } \\
\hline \multirow{4}{*}{$\begin{array}{l}\text { Compost } \\
\text { (CO.M) }\end{array}$} & $\mathrm{N}_{0}$ & 8.04 & 7.86 & 39.48 & 4.29 & 178 & 2.48 & 3.14 & 0.64 \\
\hline & $\mathrm{N}_{60}$ & 8.03 & 6.49 & 42.86 & 4.68 & 195 & 2.55 & 3.28 & 0.77 \\
\hline & $\mathrm{N}_{90}$ & 8.00 & 6.32 & 44.21 & 4.89 & 199 & 2.63 & 3.34 & 0.78 \\
\hline & $\mathrm{N}_{120}$ & 7.99 & 6.29 & 45.09 & 5.02 & 201 & 2.98 & 3.39 & 0.82 \\
\hline \multicolumn{2}{|c|}{ Mean } & & 6.74 & 42.91 & 4.72 & 193 & 2.66 & 3.29 & 0.75 \\
\hline \multirow{4}{*}{$\begin{array}{l}\text { Town } \\
\text { refuse } \\
(\mathrm{TR})\end{array}$} & $\mathrm{N}_{0}$ & 8.02 & 8.24 & 37.92 & 3.98 & 175 & 2.55 & 3.22 & 0.66 \\
\hline & $\mathrm{N}_{60}$ & 8.01 & 7.96 & 38.22 & 4.12 & 186 & 2.64 & 3.29 & 0.85 \\
\hline & $\mathrm{N}_{90}$ & 8.00 & 7.75 & 41.52 & 4.29 & 189 & 2.74 & 3.38 & 0.86 \\
\hline & $N_{120}$ & 7.97 & 7.40 & 42.00 & 4.36 & 195 & 2.78 & 3.45 & 0.92 \\
\hline \multicolumn{2}{|c|}{ Mean } & & 7.84 & 39.92 & 4.19 & 186 & 2.68 & 3.34 & 0.82 \\
\hline \multirow{4}{*}{$\begin{array}{c}\text { Farmed } \\
\text { manure } \\
\text { (FYM) }\end{array}$} & $\mathrm{N}_{0}$ & 8.01 & 7.94 & 38.94 & 4.22 & 177 & 2.55 & 3.19 & 0.65 \\
\hline & $\mathrm{N}_{60}$ & 7.98 & 7.62 & 40.66 & 4.52 & 192 & 2.60 & 3.27 & 0.79 \\
\hline & $\mathrm{N}_{90}$ & 7.96 & 6.74 & 42.87 & 4.62 & 195 & 2.69 & 3.35 & 0.84 \\
\hline & $\mathrm{N}_{120}$ & 7.94 & 6.55 & 43.69 & 4.89 & 200 & 2.99 & 3.40 & 0.89 \\
\hline \multicolumn{2}{|c|}{ Mean } & & 7.21 & 41.54 & 4.56 & 191 & 2.71 & 3.30 & 0.79 \\
\hline \multirow{3}{*}{ LSD $_{0.05}$} & $\mathrm{R}$ & & 0.67 & ns & ns & 1.73 & 0.049 & ns & 0.028 \\
\hline & $S$ & & ns & ns & ns & ns & 0.042 & ns & ns \\
\hline & $\mathrm{R} \times \mathrm{S}$ & & $\star \star \star$ & $\star \star$ & ns & ** & ** & ns & ** \\
\hline \multicolumn{10}{|c|}{ Second season (2014) } \\
\hline \multirow{4}{*}{$\begin{array}{l}\text { Compost } \\
\text { (CO.M) }\end{array}$} & $\mathrm{N}_{0}$ & 8.03 & 6.78 & 41.13 & 4.63 & 180 & 2.55 & 3.20 & 0.71 \\
\hline & $\mathrm{N}_{60}$ & 8.00 & 5.94 & 42.96 & 4.98 & 199 & 2.69 & 3.36 & 0.82 \\
\hline & $\mathrm{N}_{90}$ & 7.98 & 5.66 & 44.88 & 5.10 & 203 & 2.79 & 3.45 & 0.89 \\
\hline & $\mathrm{N}_{120}$ & 7.97 & 5.48 & 45.19 & 5.22 & 205 & 3.02 & 3.52 & 0.94 \\
\hline \multicolumn{2}{|c|}{ Mean } & & 5.97 & 43.54 & 4.98 & 197 & 2.76 & 3.38 & 0.84 \\
\hline \multirow{4}{*}{$\begin{array}{l}\text { Town } \\
\text { refuse } \\
\text { (TR) }\end{array}$} & $\mathrm{N}_{0}$ & 8.01 & 7.95 & 38.94 & 4.69 & 179 & 2.68 & 3.28 & 0.88 \\
\hline & $\mathrm{N}_{60}$ & 7.96 & 7.66 & 40.83 & 4.85 & 188 & 2.75 & 3.39 & 0.95 \\
\hline & $\mathrm{N}_{90}$ & 7.94 & 6.88 & 41.97 & 4.96 & 202 & 3.04 & 3.48 & 0.98 \\
\hline & $\mathrm{N}_{120}$ & 7.92 & 6.61 & 42.55 & 4.99 & 203 & 3.08 & 3.56 & 1.02 \\
\hline \multicolumn{2}{|c|}{ Mean } & & 7.28 & 41.07 & 4.87 & 193 & 2.89 & 3.43 & 0.96 \\
\hline \multirow{4}{*}{$\begin{array}{c}\text { Farmed } \\
\text { manure } \\
\text { (FYM) }\end{array}$} & $\mathrm{N}_{0}$ & 8.00 & 7.39 & 40.85 & 4.48 & 179 & 2.66 & 3.25 & 0.85 \\
\hline & $\mathrm{N}_{60}$ & 7.94 & 6.89 & 41.36 & 4.88 & 197 & 2.71 & 3.37 & 0.89 \\
\hline & $\mathrm{N}_{90}$ & 7.91 & 6.28 & 42.95 & 4.95 & 200 & 2.98 & 3.44 & 0.94 \\
\hline & $\mathrm{N}_{120}$ & 7.89 & 5.94 & 44.00 & 5.03 & 204 & 3.05 & 3.53 & 0.99 \\
\hline \multicolumn{2}{|c|}{ Mean } & & 6.63 & 42.29 & 4.84 & 195 & 2.85 & 3.40 & 0.92 \\
\hline \multirow{3}{*}{ LSD $_{0.05}$} & $\mathrm{R}$ & & 0.51 & ns & ns & 5.32 & ns & ns & 0.055 \\
\hline & $S$ & & 0.44 & ns & ns & $\mathrm{ns}$ & ns & ns & ns \\
\hline & $\mathrm{R} \times \mathrm{S}$ & & ** & ns & ns & ** & ns & ns & ** \\
\hline
\end{tabular}


Available micronutrients ( $\mathrm{Fe}, \mathrm{Mn}$ and $\mathrm{Zn}$ ) in soil.

The concentrations of $\mathrm{Fe}$ and $\mathrm{Mn}$ in soil at end of the experiment increased due to application of the organic amendments with or without urea. Both the organic amendments and rate of the applied $\mathrm{N}$ affected significantly Fe availability in the first season. $\mathrm{Zn}$ was affected significantly only with rate of $\mathrm{N}$ whereas the increases occurred were insignificant for $\mathrm{Mn}$. In the second season, only $\mathrm{Zn}$ was affected by rate of $\mathrm{N}$ whereas neither Fe nor $\mathrm{Mn}$ was affected significantly by source of organic amendments or rate of $\mathrm{N}$.

Organic sources contain microorganisms that make nutrients more available through decomposition of the organic matter leading to production of several organic acids (Hammad and Abdel Ati, 1998). Also, bacteria cause some micro-nutritive elements release of nutritive elements in available forms (Bhande et al. 1997). The interaction effect between sources of the organic amendments and rate of the applied $\mathrm{N}$ was significant on $\mathrm{Fe}$ and $\mathrm{Zn}$ in the first season and $\mathrm{Zn}$ only in the second one.

\section{CONCLUSION}

It can be concluded that the highest values of maize yield, yield quality and its components as well as the nutritive element content were a achieved due to application of FYM . The highest productivity of maize crop with good seed quality under saline soil conditions was achieved by using the highest rate of $\mathrm{N}$-mineral fertilizers and manuring the soil with matured organic materials such as COM, FYM and TR. Also, it could be concluded that application of organic amendments is very important due to their effects on improving soil physical, chemical and biological properties, besides compost represents a storehouse for all essential macro and micronutrients. The applied organic manure led to improve maize grain quality. Also, from the economical point of view, the use of organic manure decreases the needed amounts of chemical fertilizers and produces higher yield and better quality of maize grains with a relatively lower coast under salinity and sodicity stresses.

\section{REFERENCES}

Abbas, M.H.H., Ahmed, O.A.I., Manal, A.H. El-Gamal and Haythum, M.S. (2011). Integrated effect of mineral nitrogen, bio and organic fertilization on soybean productivity. Egypt. J. Biotechnol. 39: 43-63.

Abdel-Fattah, M.K. (2012). Role of gypsum and compost in reclaiming saline -sodic soils. ISOR J. Agric. and Veterinary Sci., 1(3): 30 - 38.

Abd El-Maksoud ,M.F. (2002). Response of some wheat cultivars to biofertilizer and nitrogen fertilizer levels . Zagazig. J. Agric. Res., 29 (3): $891-905$.

Abedi, T., Alemzadeh A. and Kazemeini, S.A. (2010). Effect of organic and inorganic fertilizers on grain yield and protein banding pattern of wheat. Australian J. Crop Sci., 4(6): 384-389. 
Ahmad, R., Ranjha, A. M. Mehdi, S. M. Hussain, M. J. Sarfraz, M. and Hassan, G. (2001). Integrated use of organic manures and fertilizers in rice-wheat cropping system. Pakistan. J. Bio. Sci. 4 (3): 184-186.

Amirjani, M.R. (2011). Effect of salinity on growth, mineral composition, proline content, antioxidant enzymes of soybean. American J. Plant Physiology 5: $360-360$.

Angas, P., Lampurlanes, J. and Martinez, C.C. (2006). Tillage and N fertilization effects on $\mathrm{N}$ dynamics and barley yield under semiarid Mediterranean conditions. Soil and Tillage Res. 87: 59 - 71

Arthur, E., Cornelis, W.M., Vermang, J. and Rocker, D.E. (2011). Amending a loamy sand with three compost types: impact on soil quality. J. Soil use management. $27: 116-123$.

Ashmaye, S.H., Shaban, Kh.A. and Abd El-Kader, M.G. (2008). Effects of mineral nitrogen, sulphur, organic and bio-fertilizer on maize productivity in saline soil of Sahl El-Tina. Minufiya, J. Agric. Res., 33(1): $195-209$.

Bates, L.S., Waldren, R.P. and Teave, I.D. (1973). Rapid determination of free proline for water stress studies. Plant and Soil, 939: 205-207.

Bassiony, H.M and Shaban, Kh.A. (2010). Economic analysis for the efficiency use of mineral and bio-fertilizers on saline soil. Zagazig, J. Agric. Res. 37 (5): 1313- 1330.

Berhanu, G.W., Kismanyoky, T. and Sardi, K. (2013). Effect of nitrogen fertilization and residue management on the productivity of winter barley (Hordeum vulgare L.). Acta Agronomica Hungarica, 61(2): 101 111.

Bhandari, A.L., Ladha, J.K., Pathak, H., Padre, A.T., Dawe, D. and Gupta, R.K. (2002). Yield and soil nutrient changes in a long-term rice-wheat rotation in India. Soil Sci. Soc. Am. J., 66: 162-170.

Bhande, S.R., Sharma, S.B. and Chougule, A.B. (1997). Effected biofertilizer in combination with nitrogen through organic and inorganic sources on yield and quality of onion. National Hort. Res. Derelop. Found. 17(2):13.

Black,C.A., Evans D.D., White, I.I. Ensminger, L.E. and Clark, F.E. (1965). Methods of soil analysis. Amer. Soc. Agron. Inc., Ser. 9 in Agron., Madison, Wisconsin

Brunner, P.H. and Wasmer, H.R. (1978). "Methods of analysis of sewage sludge solid wastes and compost". W.H.O. International Reference Center for Wastes Disposal ( $\mathrm{H}-8600)$, Dulendr of Switzerland.

Cengiz, K., Muhammsd, A. Murat, D. and Atilla, T. (2013). Alleviation of salt stress- induced adverse effects on maize plants by exogenous application of indoleacitic acid (IAA) and inorganic nutrients- Afiled trial. Austr. J. of Crop Sci. 7 (2): 249- 254.

Craswell, E.T. and Godwin, D.C. (1984). The efficiencies of nitrogen fertilizer applied to cereals in different climates. Adv. Plant Nutr. 1: 1-55.

Daneshmand, N.G., Bakhshandeh, A. and Rostami, M.R. (2012). Biofertilizer affects yield and yield components of wheat. Inter. J. Agric. 2(6): 699704. 
Diacono, M., Rubino, P. and Montemurro, F. (2013). Precision nitrogen management of wheat; a review. Agronomy for Sustainable Development. 33(1): $219-241$.

Echeverria, H.E. and Videla, C.C. (1998). Eficiencia fisiologica y de utilizacion de nitrogeno en trigo en la region pampeana Argentina. Ciencia del suelo 16: $83-87$.

El-Bana, A.Y.A. and Gomaa, M.A. (2000). Effect of N and K fertilization on maize grown in different populations under newly reclaimed sandy soil Zagazig J. Agric. Res., 27(5): 1179 - 1190.

El-Sherbiney, A. E., Soliman, K.G. and Aly, R.M. (1999). Increasing the efficiency of nitrogen fertilizers in newly reclaimed sandy soil. Zagazig J. Agric. Res. 26 (3B): 895-906.

El-Sherbieny, A. E. A., Awad, E. A. M. El-Sawy, M. M. M. and Helmy, A. M. (2003). Wheat response to some agro-industrial wastes and conventional N- fertilizers. Zagazig J. Agric. Res. 30(2): 385-406.

Ewees, M.S.A. and Abdel Hafeez, A.A.A. (2010). Response of maize grain yield to a partial substitution of $\mathrm{N}$-mineral by applying organic manure, bio-inoculation and elemental sulphur as an alternative strategy to avoid the possible chemical pollution. Egypt J. Soil Sci., 50(1): 141 166.

FAO, (2003). Food energy-methods of analysis and conversion factors. Report of a Technical Workshop. Food and Nutrition Paper, 77:7 - 11, Rome, 3 - 6 December, 2002.

FAO, (2008). Land and Plant Nutrition Management Service. Rome: FAO of UN.

Hammad, A.M.M. and Abdel Ati, Y.Y. (1998). Reducing of nitrate and nitrite content of potato tublers via biofertilization with Azospirillum and VA Mycorrhizal fungi. J. Agric. Sci., Mansoura Univ. 23(6):2597-2610.

Haque, S.A (2006). Salinity problems and crop production in coastal regions of Bangladesh. Pak. J. Bot. 38: 1359- 1365.

Hegazi, I.M.A. (2004). Maximizing wheat production in sandy soil by using some natural soil amendments. Egypt J. Appl. Sci., 19(4): $214-226$.

Jackson, M.L. (1958). Soil Chemical Analysis .Prentice- Hall, Inc., Englewood Califfs, New Jersy .

Joshi, R.A., Prasanna, R., Shivay, Y.S. and Nain, L. (2012). Biofortification of wheat through inoculation of plant growth promoting rhizobacteria and cyanobacteria. Euro. J. Soil Biology., 50: 118-126.

Kandil, A.A., El-Hindi, M.H., Badawi, M.A., El-Morasy, S.A. and Kalboush, F.A.H.M. (2011). Response of wheat to rates of nitrogen, biofertilizers and land leveling. Crop \& Enviro. 2(1): 46-51.

Khalifa, M.R., Koriem, M.A. Ramadan, S.A. and Abo-Waly, M.O. (1994). Effect of some organic amendments on sandy soil parameters and elemental composition of wheat grains. Proceedings of the $1 \mathrm{st}$ Egyptian Hungarian Conference on Environment, April 5-7, St. Catherine, Sinai, Egypt. 
Mohammed, S.S. (2002). Integrated nitrogen management to wheat through mineral and biofertilization along with organic municipal-wastes in some newly reclaimed soils of Egypt. 1- Vegetative growth, grain yield and its quality. Zagazig J. Agric. Res. 29 (2): 569-592.

Mohamed, O. M. A. and Matloub, M.A. (2007). Effect of soil amendments on some physical and chemical properties of some soils of Egypt under saline irrigation water. African Crop Science Conference Proceedings. 8: $1571-1578$.

Namvar, A. and Teymur, K. (2013). Response of wheat to mineral nitrogen fertilizer and biofertilizer (Azotobacter sp. and Azospirillium sp.) inoculation under different levels of weed interference. Ekologija $\mathrm{J}$. 59(2): 85 - 94.

Nasef, M.A., Shaban, Kh.A. and Abdel Hameed, A.F. (2009). Effect of compost and bio-fertilizer application on some chemical soil properties and rice productivity under saline soil condition. J. Agric. Mansoura Univ., 34 (4): 2609- 2623.

Nofal , F. and Hinar, A. (2003). " Growth and chemical properties of maize grow of some single crosses as affected by nitrogen and manure fertilization under sprinkler irrigation in a sandy soil. " Egypt .J . Appl. Sci ; 18 (5 B) : 583- 596.

Nour El-Din, M. and Salama, A.S. (2006). Significance of biofertilization for improving yield, chemical and technological properties of wheat plants grown in saline soil. Zagazig J. Agric. Res., 33(3): $501-515$.

Page, A.L., Miller, R.H. and Keeney, D.R. (1982). "Methods of Chemical Analysis". Part 2: Chemical and microbiological properties (Second Edition). American Society of Agronomy, Inc. and Sci. Soc. of America, Inc. Publishers, Madison, Wisconsin U.S.A.

Piper, C.S. (1950). "Soil and Plants analysis." A monograph from the water. Agric. Res. Inst., Univ. of Alediade, Australia.

Poraas, M.M.E., Salwa, A.I. Eisa, Shaban, Kh.A. and Sallam, A.M. (2008). Effect of applied organic and bio-fertilizers on the productivity and grains quality of maize grown in saline soil. Egypt J. Soil Sci., 48(4): $485-500$.

Raafat, N.Z. and Tharwat E.E.R. (2011). Improving wheat grain yield and its quality under salinity conditions at a newly reclaimed soil using different organic sources as soil or foliar applications. J. Appl. Sci. Res. 7(1): 4255.

Rabie, M.H., Negm, A.Y., Mona, M.E.M. and Abd El-Sabour, M.F. (1997). Influence of two sewage- sludge sources on Faba bean and sorghum plants growth and elements uptake. Egypt. J. Appl. Sci. 37 (4): 425435.

Rashed, S.H. (2006). " Effect of bio and organic fertilization on Zea mays ". MSc. Thesis, Fac. of Agric. Mansoura Univ. Egypt.

Rashed, F.M., Kesba, H.H., Saleh, W.D. and Moselhy, M.A. (2011). Impact of rice straw compost on microbial population plant growth nutrient uptake and root-knot nematode under greenhouse conditions. Afr. J. Agric. Res., 6: $1188-1203$. 
Ryan, J., Garabet, S., Harmsen, K. and Rashid, A. (1996). "A soil and plant analysis". Manual Adapted for the West Asia and North Africa Region. ICARDA, Aleppo, Syria, 140.

Saric, M.R.K., Cupina, T.and Geric, I. (1967). Chlorophyll determination. Univ. U. Noven Sadu Prakitikum is Kiziologize Bilijaka Beogard, Haucna, Anjiga.

Sarwar, G., Schmeisky, H., Hussain, N., Muhammad, Ibrahim, S.M. and Safdar, E. (2008). Improvement of soil physical and chemical properties with compost application in Rice-wheat cropping system. Pakistan. J. Bot. 40(1): 275-282.

Siam, H.S., Shaban, Kh.A. and Safaa, A.M. (2013). Evaluation of applying different mineral nitrogen sources on soil fertility and wheat productivity under saline soil conditions. J. Applied. Sci. Res., 9(4): 3146 - 3156.

Snedecor, G.W. and Cochran, W.G. (1971). Statistical Methods $6^{\text {th }}$ eddition. lowa State University Press, Ames. lowa, U.S.A.

Soltanpour, N. (1985). Use of ammonium bicarbonate - DTPA soil test to evaluate elemental availability and toxicity. Soil Sci. Plant Anal., 16: $323-338$.

Watanabe, F.S. and Olsen, S.R. (1965). Test of an ascorbic acid method for determing phosphorus in water and $\mathrm{Na} \mathrm{HCO}_{3}$ extracts from soil. Soil Sci. Soc. Am. Proc., 29 : 677 - 678.

Witham, F.H., Blaydes, D.F. and Devin, P.M. (1971). Experiments in plant physiology. Van Nosland Reihold. Co. New York, 55-58.

Wortman, S.E., Davis, A.S., Schutte, B.J. and Lindquist, J.L. (2011). Integrating management of soil nitrogen and weeds. Weed Sci., 59: $162-170$.

Yadvinder, S., Singh, B., Ladha, J.K., Khind, C.S., Gupta, R.K., Meelu, O.P. and Pasuquin, E. (2004). Long-term effects of organic inputs on yield and soil fertility in rice-wheat rotation. Soil Sci. Soc. Am. J., 68: $845-$ 853.

Zaka, M.A., Mujeeb, F., Sarwar, G., Hassan, N.M. and Hassan, G. (2003). Agromelioration of Saline Sodic Soils. J. Biol. Sci. 3(3): 329-334.

Zaka, M.A., Obaid, U.R., Rafa, H.U. and Khan, A.A. (2005). Integrated approach for reclamation of salt affected soils. J. Agric. and Soc. Sci., 1 (2): 94-97. 
كفاءة التسميد النيتروجينـي للذرة النـامي تحت ظروف الأراضـي الملحيـة الصودية

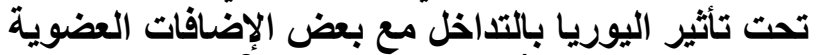

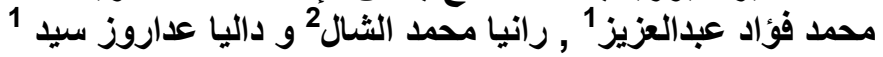

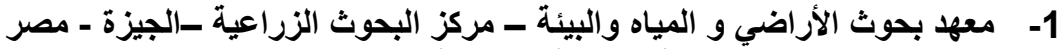

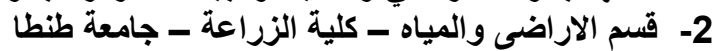

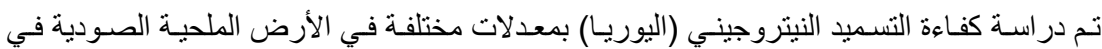

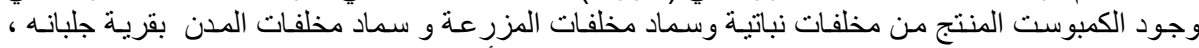

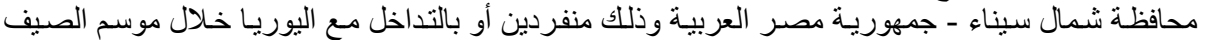

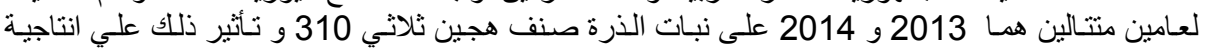

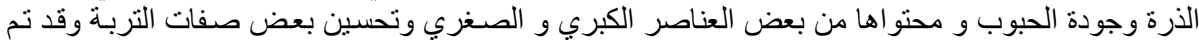

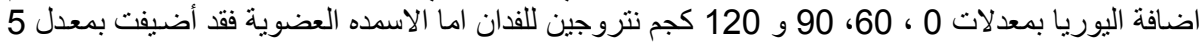

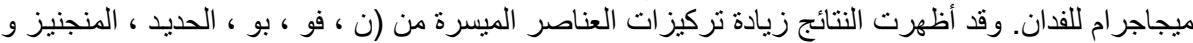

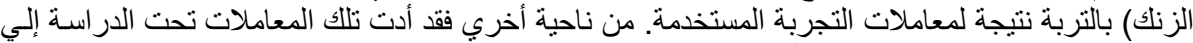

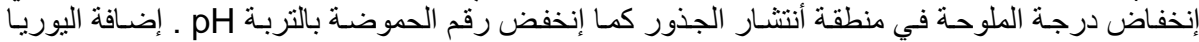

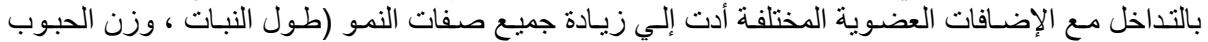

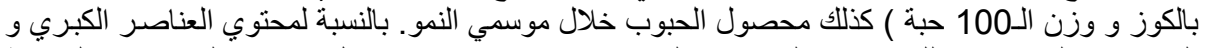

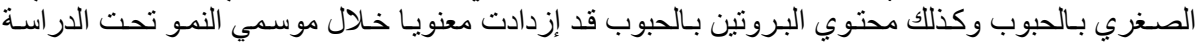

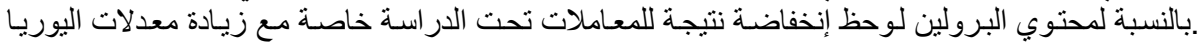

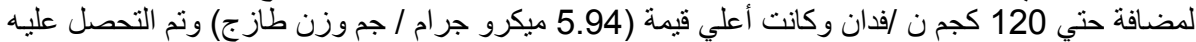

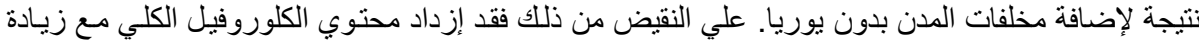

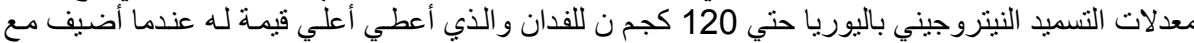

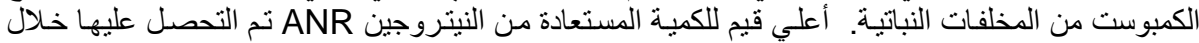

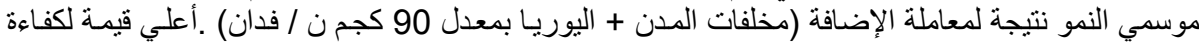

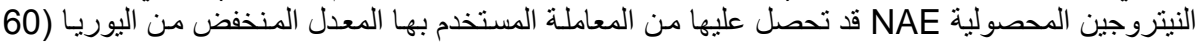

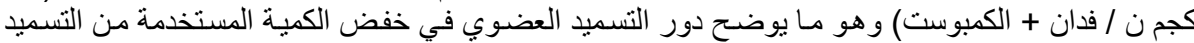

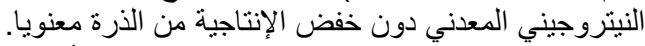

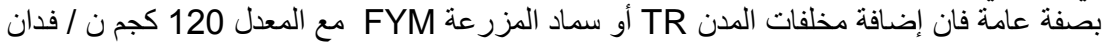

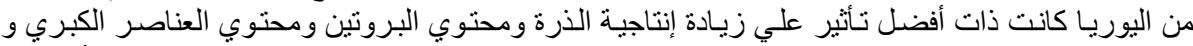

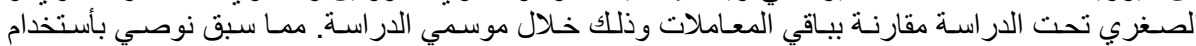

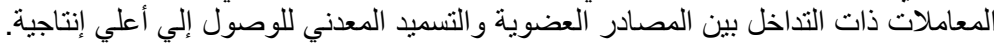

